\title{
Metacognition as Methodology for Continuing Education of Teachers
}

\author{
Evelise Maria Labatut Portilho', Giovanna Beatriz Kalva Medina ${ }^{2,3}$ \\ ${ }^{1}$ Postgraduate Strict Sense Program of Education, Pontifical Catholic University of Paraná (PUCPR), \\ Curitiba, Brazil \\ ${ }^{2}$ FAE University Center, Curitiba, Brazil \\ ${ }^{3}$ Federal University of Paraná (UFPR), Curitiba, Brazil \\ Email: eveliseportilho@gmail.com,giovannabkmedina@gmail.com
}

Received 14 October 2015; accepted 11 January 2016; published 14 January 2016

Copyright () 2016 by authors and Scientific Research Publishing Inc.

This work is licensed under the Creative Commons Attribution International License (CC BY).

http://creativecommons.org/licenses/by/4.0/

(c) (i) Open Access

\section{Abstract}

In Brazil, the discussion on teacher education has been expanding and deepening due to numerous factors, including the quality of education and teachers' professional development. As a consequence, it is observed a decrease in demand for the teaching career and the students' low performance in national and international research on learning assessment. Therefore, there is an urgent need for investment in the continuing teacher education, considering the meeting of peers in their own context in which the pedagogical action happens. This article presents the research developed in a Municipal Early Childhood Center of Curitiba/Paraná/Brazil, aiming to describe and interpret the metacognitive methodology used in continuing education of 32 teachers, according to hermeneutic phenomenology. The thematic and dynamic observation records performed in 6 meetings with the participants were used as the research instrument. The results indicate that the participants have, in principle, resistance to a new model of continuing education, mainly because it runs away from the routine established in the institution and by the unfamiliarity with the reflective practice. On the other hand, an aspect highlighted by the group was the opportunity they had to relate the life experience with the work experience. The data confirm that metacognition as methodology for continuing education gives space within the institution so that teachers can talk, listen, discuss and learn with their peers; as well as it enables to look at themselves and at their professional performances, with view to joint and effective actions.

\section{Keywords}

Learning, Teacher Education, Metacognition, Early Childhood Education 


\section{Introduction}

The changing scenario, featuring contemporaneity, alters the teachers' dynamic demands and requires adaptation and integration of methodologies that respond to a teacher's profile which understands the multidimensionality of the world and of human beings, as well as transforms their attitudes towards their students' learning.

The initial as well as continuing education requires the development of skills for the practice of teaching, such as knowledge mobilization, transforming them into action.

Continuing education is one of the tools for both sensitization and awareness of teachers regarding their practices and for decision making toward the enhancement of students' learning. Hence the importance of choosing a methodology aimed to deal with such requirements.

The metacognitive approach in a continuing education program encourages learning to learn when requesting the awareness and regulation of cognitive activities from its participants toward the practice transformation. For the teacher, this methodology involves reflection on their skills and limitations in planning, monitoring and evaluating their teaching practices with their peers.

Revisiting the state of knowledge on the subject of metacognition and continuing education of teachers was able to find works about continuing education conducted in their own working environment (Fernandes, 2000; Silva, 2004; Hollanda, 2007; Fernandes, 2008; Zapelini, 2009), continuing education which focuses on the discussion among peers (Sato, 2006; Zapelini, 2009), and the importance of reflective practice in continuing education (Segat \& Grabauska, 2004; Vignado, 2007; Abianna, 2009), however about metacognition what stands out most is research concerning the construction of instruments (Schraw \& Dennison, 1994; Balcikanli, 2011) to assess meta-cognitive practice in teaching practice. Therefore, the originality of the present study compared to others involving continuing education is the proposal of a methodology that embraces the metacognition of the assumptions in the teaching learning.

Postholm (2012) found in his work that both individual and organizational factors influencing the teaching learning. Cooperation between pairs, a positive school culture, the understanding of the learning of teachers and the support of external tutors are important requisites for continued teacher training, emphasizing that the school environment is the best place for teacher's professional development.

From this, there is the need to study on training preschool teachers (Meinicke \& Portal, 2014), focusing on the construction of knowledge and research in their own environment where practice occurs.

Thus, this paper presents the research carried out in a Municipal Early Childhood Center (MECC) in Curitiba/Parana/Brazil, aiming at the description and the interpretation of a program for teachers' continuing education in early childhood education with the adoption of metacognitive methodology.

\section{The Metacognitive Perspective on Teachers' Continuing Education}

Metacognition is understood as the knowing of knowing itself, or even learning how to learn. This concept "includes any knowledge or cognitive activity that has its goal or adjusts any aspect of any cognitive enterprise" (Flavell, Miller, \& Miller, 1999: p. 125). In other words, metacognition proposes a reflection on how it develops a cognitive activity, considering this complex action, as it includes the awareness, control and transformation in the way we act in a learning situation. An example of metacognitive activity is when, before we elaborate a work project, we consciously analyze the steps to be taken and the material we have available, and only then we know if we should start it immediately or not. So, the procedure employed to undertake the project is the cognitive activity itself.

By becoming aware of oneself, one gains the ability to analyze the requirements of the task to be performed and relate it to the reality that presents itself. It can reflect on the information, determine the purpose of the activity to be met, observe what is new and familiar and detect the difficulty levels, deciding where and when to start.

Relating metacognition to continuing teacher education, we propose a process which gives the teacher the opportunity to think about how to learn, and consequently, how to teach, with a view to redefining their pedagogical practice and their perception as researcher of this practice.

Continuing education with metacognitive bias makes indispensable the involvement of teachers as "active participants in their learning, focusing their attention on critical elements, encouraging abstraction of themes or common procedures and allowing them to assess their own progress towards understanding” (Bransford, Brown, \& Cocking, 2007: p. 97).

Metacognition has important implications for the pedagogical practice, especially regarding teacher learning 
and the ability to teach metacognitive strategies to students, but for this to be possible, this practice must be incorporated by the educator.

For the teacher, the attitude of thinking about thinking itself, to learn about learning itself, is the opportunity to expand the possibilities of self-understanding and understanding of others and the world.

As this research was conducted in the work context of teachers of a given Municipal Center for Early Childhood Education, continuing education in metacognitive modality implies the redesign, the research and acting together with peers.

\section{Early Childhood Education Teachers Continuing Education}

Currently, the challenges of the teaching profession require continuous teacher education, understood as a process that, in addition to constantly review their pedagogical practice, their style as teachers, their professional skills, it enables the collective construction with the peers. It is effectively a personal and professional investment. Nóvoa (1992: p. 25) adds that this type of continuing education:

[...] should stimulate a critical and reflective perspective, providing teachers the means of an autonomous thinking and to facilitate the dynamics of participatory self-education. Being in training implies a personal investment, a free and creative work on the pathways and own projects, with a view to constructing an identity, which is also a professional identity.

The author emphasizes that teacher's continuing education requires involvement, investment and active attitude, essential aspects for the construction of autonomous thinking.

As it can be observed, many factors must be present at the time of drawing up a teachers' education program, spanning from reflection, involvement and willingness from each one up to issues related to educational institutions, such as methodology, curriculum, line of study and the own historical, political and social context in which the teacher is inserted.

The concept of teacher education highlighted by Garcia (1999: p. 26) emphasizes teacher education as the educator's learning experience that is in constant process of acquiring knowledge:

[...] teachers-in training or exercising their profession — are involved individually or in a team, in learning experiences through which they acquire or improve their knowledge, skills and dispositions, and allows them to act professionally in the development of their teaching, of the curriculum and of the school, with the goal of improving the quality of education that students receive.

The objective of this type of learning consists in the teacher to mean new knowledge for the improvement of teaching and hence student learning. This is because being a teacher is to be a constant learner.

On the other hand, Oliveira-Formosinho (2009: p. 225) uses the term "professional development" when referring to the continuing education of teachers, explaining that "it is a more experiential and more integrative process than continuous education. It is not a purely individual process, but in context”. When making reference to professional development, the author highlights the personal enrichment of students and group and permanent character of this type of education.

In the National Education Guidelines and Framework Law No. 9394/96 (Brazil, 1996) the terms continuing training, continuing education and continuing professional development are employed to address the investment that teachers and institutions must devote to the improvement of the teacher's practice and professional career. In this law, the concept of the terms is not developed, giving rise to the interpretation that best fits the intended study.

As teachers of Early Childhood Education (ECE), the Guidelines and Framework for Municipal Education Curitiba (Curitiba's Department of Education, 2006) state that continuing education should be developed, preferably in service, and create opportunities to give "space for reflection on the linked practice to the expectations of a professional who acts not dissociated in this educational stage" (p. 33). These guidelines emphasize that "the quality of early childhood education depends on the quality of the professionals' education who work directly with children” (p. 33).

Continuing education of the professionals at the Municipal School System (MSS) aims to "deepen concepts, reflect on their practices and support the work" (Curitiba's Department of Education, 2009: p. 65), and it can be developed in various ways, such as: courses, lectures, workshops and educational meetings held during the teachers' weekly period stay ${ }^{1}$ at school. It is worth to highlight that the certificates from continuing education

${ }^{1}$ The term "period stay" is used to refer to the time stay in school corresponding to $20 \%$ of the weekly 40 hour journey of the educators. This weekly time period was established by Law 12,348 dated 16 August, 2007, and it gives the opportunity for organizing, planning and continuing education of teachers during school working hours. 
contribute to the increase in jobs and salaries of the professionals' plan and become an incentive for its implementation.

For the context of this research, the term continuing education is adopted as a process in the life cycle of teachers that depends on their involvement when wanting an internal change (learning) that can bring about a transformation in their practice in the classroom. Preferably, continuing education should start from the need of teachers and the educational environment where they are inserted, and consider their beliefs, values and representations.

\section{The Methodological Path}

This qualitative research study describes an experiment in continuing education and interprets phenomena according to hermeneutic phenomenology, which, in turn, reveals the facts by means of reports, in seeking to interpret them with reflection (Coltro, 2000).

This proposal not only describes the voices, the speech and the subjects' language, but it also interprets what the educational environment communicates.

The context in which the research was conducted is a Municipal Early Childhood Center (MECC) in Curitiba that caters to children ages 3, 4 and 5. Professionals who agreed to participate in the training are 32 teachers working in the morning, being 16 teachers and 16 educators, all female, aged between 26 and 61 years, with 15 of them aged between 30 and 39 years. The oldest teacher possessed 39 years of work as a teacher. The other teachers and educators possessed an average of 15 years of teaching. All are civil servants, and most of them have higher education course, only 2 educators have only high school. For description of the data, the teachers are identified by the letter "T" followed by a number from 1 to 16 , as well as the educators, identified with the letter "E" followed by a number from 1 to 16 .

In institutions of Early Childhood Education in the Municipal School System in Curitiba/Parana/Brazil, there are positions for teacher and educator; the first must have higher education to work a standard four-hour day period, while the second must have completed high school to work for a period of eight hours/day, because this position doesn't need better training. The educator's salary is half of the teacher's. In this CMEI each class has an educator working with a teacher and even without the requirement, 14 educators have higher education. The teacher is responsible for the class and their learning, the educator helps teacher with the children needs.

In preparing this model of teacher continuing education, the purpose was aimed at promoting a space for meeting and discussion between peers, in the place where the work happens. Metacognition understood as a reflection on the action was the way found to illuminate the continuing education process proposed in this research, since the teacher and the educator were invited to be researchers of their pedagogical practice.

This education program was developed in six meetings lasting an hour and a half each, in two different groups, and these are called group 1 and group 2. A year after the last meeting, the feedback session data for school directors and teachers from MECC was held.

The topics discussed at the meetings were about: professional identity, teacher's social and professional representation; educational environment, learning styles, childhood and infancy conceptions, evaluation and closing.

These meetings were structured to favor moments of awareness and regulation of activities involving the teaching practice. They all started with the so-called "task review", whose goal was to revisit the issue discussed in the previous meeting, which should in turn be applied to reality through a survey instrument. The second phase of the education program, called "trigger", talked about a specific topic related to the theme of the meeting, presented orally or dynamically. The third moment was the "conversation wheel", featured as the space in reworking as a group the theme of the day, powered by an initial set-point. On the fourth moment the teachers were invited and given instruments to research, in the interval between meetings, their practices. The fifth moment was arranged for the "evaluation", being then, submitted questions to be answered by the group.

It is important to highlight that the education process should be observed and recorded considering the theme, that is, what is said in the group and the dynamics, what is lived.

Continuing education in the metacognitive perspective proposes to encourage the teacher to become a researcher in their pedagogical practice. In this direction, we selected the three moments from the education program to be considered in this research: resuming the task, the conversation wheel and the evaluation, since they nurture the personal and group reflection through different instruments. 


\section{Results}

\subsection{Moment for Resuming Task}

In the space designated for the "resuming the task", some reports about the meetings illustrate the involvement of teachers and educators in the continuing education process.

In the first meeting, where the task was related to preparing the memorial on the personal choice to be a teacher of early childhood education in teachers and educators group 1, only two teachers had the task at hand. In the report below, we notice the presence of a preconceived notion regarding the term task, as one more obligation in their teaching activity.

T8- “Was it to be turned in today?"

T2- "Only the educator did it (referring to the colleague, the educator, who works in the same classroom)."

T1-It's what I've already said, it's my story... In a nut shell: the key points!"

T2-“Me too, me too!"

T1-“I thought it was going to be boring to do it... I missed a family event to do the work. I can't... It's not that I don't like it, but I never thought I would be an early childhood education teacher, because of the work you take home. My grandmother was a teacher; my mother was one too."

The limited participation in the task, the difficulty or lack of practice in recording something personal can denote the distance between the research attitude and practice, as stated by André (2001: p. 59), when he stresses that "not always there is time for a detachment and an analytic attitude as in the research activity. This does not mean that the teacher should not have an investigative spirit".

At the second meeting, a larger number of teachers and educators had done the requested tasks: the drawing of the teacher and the first diary of the teacher and the student. Some expressed difficulties in doing the activities, as presented in the dialogues below:

E1-“I had a doubt. Enough time for the children to do the two drawings. They can't. The first drawing the children do it, and the second one doesn't come out. It has to be quite fast otherwise they forget when to ask.

For them it's the same thing (what the teacher taught and what you learned). I had to review the content well for them to understand, and then apply the diary."

Coordinator- "Do you think there is an excess of material?"

T1- "Not for us, but for the children. The questions are not in agreement. The drawings are representative at the time they're done. For example, in my classroom the questions were asked almost at the time the children went home, by then they already didn't know what they had drawn and said things that had nothing to do with it."

T14- "I don't know who thought up the questions, but they are too difficult for the age range of the children. I work with Early Childhood Education, with Elementary Education and with adults and the difference among them is big. This type of question starting at 8, 9 years old may be they can understand."

E1-"What they know is the verb to play; what was taught and what was learned it's going to be adjusted at the Elementary Education."

T14- "The verb to teach, to learn has no meaning for them."

E16- "I agree. May be the children from kindergarten are able to."

E16-“Impossible."

T14-“Not even with the kindergarten it's possible to do. Only with 8 and 9 year olds."

In the speech, it is observed that the teachers demonstrate the search for a favorable outcome in the activities done with the children. There were no questionings or problems found on the children's performance, but only negative statements, which indicates a distancing from the investigative look up to that point.

A questioning attitude is one of the characteristics of the teacher researcher, as André (2001: p. 60) points by stating that "there must be a personal willingness by the teacher to investigate and a desire to question" beyond the minimum conditions afforded by the institution, such as time and space to research.

In the fifth meeting, teachers and educators had to report how they applied the Portilho \& Beltrami Learning Styles Inventory (2011) with children. They brought their questions and exposed the difficulty that young child- 
ren had to respond to the instrument, as shown in the following dialogue:

Coordinator- “How was the task? What was it?”

Group- "The inventory".

E1-“I didn't apply it. I also didn't do it because I was absent, right?"

Coordinator- "It is important that you go through this experience. What we are asking is this: what did you think."

T4- "There were many who were not four years old yet. Some students get lost and on my cards I recorded

that. With the five-year olds it didn't work."

Coordinator- "This is cool information for us to notice. And did you notice any good point?"

T4-“No, nо."

E12- "They always had two answers. There was no answer there and I didn't write it on the side. I forgot

at the time."

T10-“Yes. We had to change it and then they understood."

What is observed in the dialogue is the resistance in carrying out an activity that leaves the pre-set routine. When referring to the difficulty of the child, the teachers do not put themselves as participants in the educational relationship.

The proposed activities in continuing education were intended to encourage the teachers to look for the learning process of the children in an integrated way into their work. Morin (2001: p. 15) reinforces this idea when he points out that the school teaches to "isolate objects, separate disciplines, dissociate problems instead of reuniting and integrating”.

During the period of continuing education there was an increase in the number of tasks performed, which is not proportionate to the quality of implementing them. The teachers' attitudes lead us to inquire about the type of continuing education to which they are accustomed to participate, the model of sitting, listening, complying with the time and going away. When they were invited to another type of activity which demands an active involvement, resistance appears.

\subsection{The Moment at the Conversation Wheel}

Metacognition understood as learning to learn, in this research, guides the choices of the adopted instruments and the attitude to be achieved, since the intention of this education model is to develop the mental activity of reflection, leading the participants to become aware, in controlling and transforming their practices.

The conversation wheel was the privileged moment in which teachers and educators dialogued about the meeting's theme, with the opportunity to exchange experiences and reflect together.

At the first meeting, when each one had to explain the choice to become a teacher and educator, all listened intently to their colleagues' explanations, but there was no exchange between them, because time was short.

At the second meeting, when the teachers were asked to talk about the social representation of the teacher of early childhood education, it was observed that the group 1 underscores that the function of this professional is related to the care in the assisting perspective and the devaluation of the profession due to low salaries, as highlighted in the reports of P13:

"We receive little support for this. In practice it is for working parents, to have a place to leave their children: careful. They prioritize care and they do not worry with what is needed to develop the work."

"Yesterday, during the interview, the last question was about the salary, right? Of course, they make a huge terrorism regarding the teacher, as a poor wretch, in some situations it is the salary that stands out, but the lack of appreciation is general and it is not only the salary issue."

In group 2, we point out that the representation of the teacher is related to the maternal role, as it can be seen in the statements:

Coordinator-“Aunt and mother... how is the perception of whom we are?"

T2- "It is all right what I am."

T8-“Education professionals!”

T6-“You are everything at the same time!"

T9-“Aunt, society has already imposed. But whatever they call you, you are the teacher." 
We noticed the unfamiliarity of teachers with the reflecting act from what they think about social representation of the early childhood education teacher. It was common to observe in their speech the difficulty in positioning themselves in an autonomously way, advocating a particular position on the influences of the environment in which they operate.

The purpose of this education program is to get teachers to reflect on their beliefs and attitudes, as presented by Perrenoud (2002: p. 59), when emphasizing that the teacher should be:

Able to recognize in himself attitudes and practices of which is not aware and that, inclusive, even tries to ignore. It is not pleasant to admit that we do not control all our acts and all our attitudes, and it is even more unpleasant to perceive that what we ignore is not always pleasant.

The awareness of their attitudes and positions contributes to the appropriation of autonomy by the teachers, who no longer search outside themselves the responsibility of their problems, but to look at themselves, to understand the importance of their involvement in the transformation process.

At the third meeting on the educational environment, the conversation between the teachers and educators pointed out issues related to classroom space, going beyond the physical aspect, as exemplified in group 1:

\section{E7-“I think the classroom environment depends who you work with... If it is organized or not."}

E7- "In the morning, for example, the classroom is bigger, but it is not as well used, it is not good, and my classroom in the afternoon is smaller, but it has a lot of little corners, and it is used much better."

T13-"We have little space. There are 2 teachers in the morning and two others in the afternoon. It is complicated. They asked to fix the little corners, they brought texts and we studied them, but and the resources to fix the little corners?"

T16-"Before, when I started here, everything was with hollow bricks, closed with coiled paper, full of mold... Lighting is still missing, there is no space."

At this meeting the group presented a larger movement towards the reflective attitude, when they highlight the importance of the other and of themselves, as co-responsible for the use of the environment.

At the fourth meeting, the teachers and educators talked about the relationship between the teaching style and the learning style of each. It was observed that this theme has caused more participation, perhaps because it is related to the day to day teaching practice. T10 stated in Honey-Alonso Learning Styles Questionnaire (Portilho, 2009) that her predominant style is reflective, while T13 marked characteristics of active and pragmatic, and T12 said she is reflective.

T10_ “I am more reflective; I do not give content just for giving it; I need to question it."

T13- "Style independent does not mean that you leave an action aside. I am much more than that; I do not leave aside reflection, theory. The style prevails, but you end up doing everyone."

T12- In practice I am reflective. My learning style is reflective, and teaching style is active. From that practice, another one comes up and keeps growing, growing. In the group I am shier, in the classroom I am a transformer, I talk, I am active. In the group I am quieter, more of an observer."

The discussion in this conversation wheel has again shown the difficulty of the teachers in becoming aware of how they learn and therefore how they teach. In T12 and T13's speech it was observed the fragility in mastering the concepts of learning and teaching, especially when they dichotomize the actions. On the other hand, T10 and T13 pick out refection as something positive on the teaching practice, but without consistency about the real meaning of the term.

For the teacher, the attitude of thinking about its own thinking, to learn about its own learning, is the opportunity to gain autonomy to take on their learning (Placco \& Souza, 2006), because learning is a mental activity that expands the possibilities for self-understanding and understanding the other and the world.

At the fifth meeting of the conversation wheel aimed to identify how teachers perceive themselves in the role of teacher and educator. T4 presents in her speech both the importance of what the child already brings as learned and the influence of the environment on their learning. E1 and E13 highlight the need of intervention in the environment:

T4-“I only come in if so and so have difficulty in going up or down."

E1-“My intention is to play."

T4-“If you say something, you're already interfering."

T1-“You have to be careful with what stimulates a child. We have to be careful in thinking in everything." 
E13- "You have to be careful because sometimes you think you said something very simple and the child carries it forever."

T4- "They pick up our ways. The more we study, the more we have to study."

In this brief discussion, we observed that the perception of some teachers in relation to their role is to let the child lead the activity, as in the case of T4 who only gets close when the child has a difficulty, excluding her commitment of protagonist with the child. In the case of P1 and E13 what stands out is the care that the teacher should have in what is presented to the child, indicating a teaching perception that permeates the responsibility with the student's learning. "Metacognition, like other forms of learning, is gradually developed and depends both on knowledge and experience” (Bransford, Brown, \& Cocking, 2007: p. 136), that is why it is special for each teacher.

At meeting six about the continuing education process evaluation, there was not a specific time for the conversation wheel because the task was to perform a single construction, to represent everything they had learned, and at the same time headed the group's farewell along the path taken. Some statements taken from the final moment, "What would you put in a symbolic way, inside the box so we can take?" denotes a walk toward the personal reflection on the work done:

Group 1:

T10- “The return."

E11-“Opening, flexibility of the group."

T10_-"A tie between college and school."

Group 2:

E15- "The bad things I remove from the box. But about the context I liked, I really liked. I loved my childhood."

T2-“Knowledge so that this research be efficient. We know of our importance, but when you, it is very good for us to know the result."

E12- "Opportunity to know the past."

T1-“Happiness. It was very nice to remember my childhood. I want to put a jaboticaba ${ }^{2}$ that I love."

From the statements presented we highlight the opportunity that the group had with this model for continuing education, of relating the experience of life with the work experience.

The action of resorting to memory itself and reflect about the findings become a necessary exercise among educators, to recognize the practice as an instigating knowledge source. At the same time, they incite and value thinking about their own actions involved in the educational act (Placco \& Souza, 2006: p. 56).

\subsection{The Meeting's Evaluation Moment}

The evaluation was the last moment of the meetings, whose purpose was aimed at promoting reflection on what teachers and educators have taught and learned. According to Veiga (2009), the evaluation is helping learning as a constant means of equipping the individual for his self-assessment, that is, to assess his own learning.

We point out some statements:

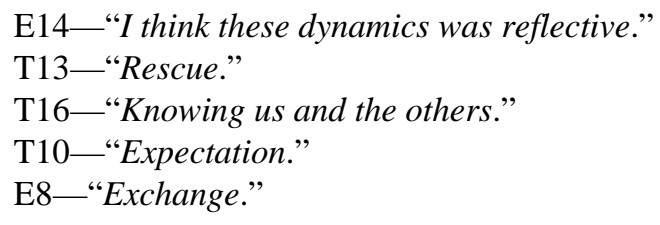

The content expressed by the teachers in this first meeting was insufficient to be able to assess whether or not there was reflection on the topic presented. The concern with the time of leaving interfered in the execution of the activity.

At the second meeting, about the social representation of the early childhood education teacher, the evaluation was represented by the following words: "wisdom", "diversity", "patience", "integration", "attention" and "reflection". As it can be observed, the group only puts single words to express what they learned and taught, de-

\footnotetext{
${ }^{2} \mathrm{~A}$ kind of fruit in Brazil.
} 
monstrating difficulty in reflecting on their role as learner and instructor, or even the little familiarity with this type of activity.

At the third meeting about the educational environment, the statements were about the content presented, as in the examples:

T15-“I think that the issue of knowing that every environment can be educative."

E7- “And the environment is not only what it has, but what was prepared, as I prepared this environment."

T13- "It was expanded to see the intentionality of this space. It is essential that the look is sharpened more,

to see if it is what I want for myself and for the children who I am responsible for. Will there be some way

to improve this environment?"

T12- "I reflected a lot... In Early Childhood Education teachers try to change this environment, making it more welcoming. Now, in Elementary School you go into the school and the classrooms are all alike."

T10- "Everything has a hidden objective there and if you want, it changes your environment to reach your ideal.”

At this meeting, we emphasize the qualitative difference in the evaluation expressed by the reflection on the learned and taught: "every room can be educational," or "change your environment to reach your ideal".

At the fourth meeting, the evaluation showed the satisfaction of the teachers and educators with the theme that was worked, when expressions such as these were said:

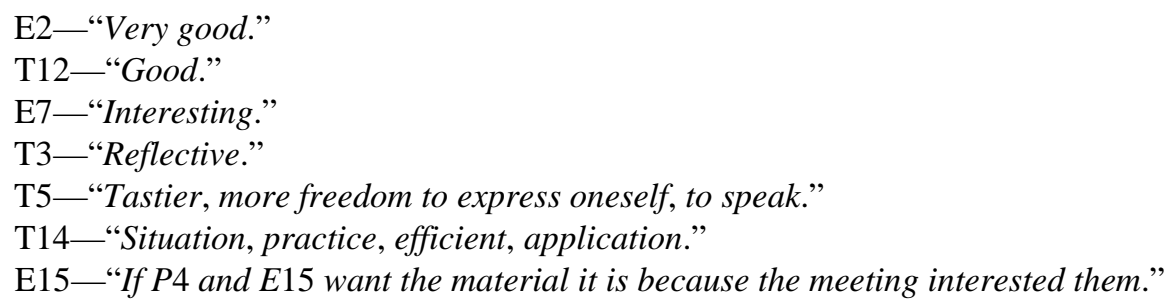

In this evaluation, the teachers mentioned the learning they had and the possibility of combining theory and practice, by contacting a content that can be used in the classroom. Tardif (2006) mentions the knowledge that the teacher needs to be able to hold so it can be done, that is, it is necessary to have a sense of what the teacher learns and what he will apply, and that this knowledge is constructed, modeled and used in a significant manner for each professional.

At the evaluation of the fifth meeting about Infancy and Childhood Conception, teachers and educators were asked to write on cards and then present to the group: "if the meeting was a child activity, what would it be?"

T14- "The conversation wheel because we do the same thing with the children."

T4-"Mine would be a corner to play."

E1-“Conversation wheel and storytelling."

E10_-"Hit the ball or pass the ball."

E9-“Conversation wheel."

T6-"Pass the ring."

E12-“Storytelling."

E2-“Did not talk and put it straight into the box."

Some teachers mention the activities that resemble the everyday at the MECC, which in turn allow a space for listening and exchanges. However, other teachers put children's activities, such as the playing corner and pass the ring, randomly.

At the sixth meeting, the final one, teachers were asked to say good-bye to each other, putting in a box, in a symbolic way, something that the research team could take with them.

It follows the report of teachers and educators from group 2:

E1-“The time already came...-I remember this song."

T4-“Araketu ${ }^{3}$ music was put it, children's play."

E10_-"Perseverance. New conducts."

${ }^{3}$ It's a Brazilian band music. 
E1-“The value of human life.”

E16-“Hope."

T4-"All the people think in helping the other, really."

T3-"Childhood, the conception we come back with good things, it is the best phase of life."

E15- "Gratitude-Everything that we started. The role you wrote. I even feel sorry. I come to thank you because we get away from the routine. It was possible to get to know you, the childhood, why you chose this profession and the rescue. This knowing you made an impression."

In the three moments of continuing education, retaking the task, the conversation wheel and evaluation, it was possible to observe the evolution of the teachers to be involved in this process. It is not possible to measure the learning built by the participants, however, the oral and dynamic testimonies demonstrate the group's concern facing some challenges, making them project some future actions regarding their practices.

\section{Upon Reflecting the Continuing Education Program}

On the research presented, it should be noticed that the metacognitive methodology in continuing education provides a space within the institution itself, so that teachers can talk, listen, discuss and learn with their peers. It also provides an opportunity to take them to look at themselves, for their professional performances and how they present themselves in the educational environment in which they operate.

It was possible to verify that the design of the meetings is suitable for the proposed objective, requiring adjustment in relation to the time of each meeting — at least two hours; at the time of the conversation wheel—was enough for the reworking of the theme in the group; the change of the term "task" by turning it into an expression that in Portuguese, sent back to the obligation and not the involvement, as it was desired.

Regarding the time directed to the presentation of the completed tasks between the meetings, it was observed that teachers at times demonstrated not to understand what was to be done, which might have caused the difficulty and delay in delivering the tasks, within the stipulated period. The teachers did the activities as an obligation and not as an integral part of the learning process. It was also noticed regarding the tasks, attitudes of resistance due to the interference in the routine established by MECC.

During the moments of the conversation wheel, it was highlighted the difficulty of teachers and educators to discuss, develop and build common concepts. Most of the time, they presented their opinions individually, without discussing in the group and with the group. The teachers had higher academic education, but at the time of relating theory with practice they had problems in the exercise of reflecting towards transformation. The oral participation of the teachers at this time of the education program occurred gradually denoting, possibly, the little unfamiliarity with this type of activity.

When the evaluation came, the final moment of each meeting, the participation of the teachers, at first, was brief and restricted to comply with the activity. From the third meeting on, it was observed that the statements gave evidence of reflective attitude, because the teachers and educators began to include themselves in the speech, that was, they put themselves as co-responsible on the student learning.

A plan for continuing education as presented in this research should be constantly evaluated depending on the natural motion of each group of teachers. Thus, there is a need to include an evaluation moment of the meeting held by the researchers, for the necessary re-adaptations, according to the dynamic character of the metacognitive methodology.

As shown by Mateos (2001), a reflection on the teaching action itself is the most promising way for teachers to efficiently and effectively regulate their teaching strategies and can thus get closer to the goal of "teaching to learn”.

\section{Acknowledgements}

We thank the participating teachers and educators for all contribution, because without them our study could not be done, and the group of researchers who we belong, called Learning and Knowledge in Education (GAE), from PUCPR, which contributed to the discussions of our work.

\section{References}

Abianna, I. C. B. (2009). Teachingpractice of Professional Trainers in Continuing Education Courses for Teachers: Anaction-Reflection Experience (Prática docente de profissionais-formadores em cursos de educação continuada de 
professores: uma experiência de ação-reflexão) (160 p). Dissertation (Master Degree), Porto Alegre, RS: Postgraduate Program of Education, Pontifical Catholic University of Rio Grande do Sul.

http://tede2.pucrs.br/tede2/bitstream/tede/3598/1/410902.pdf

André, M. (2001). The Role of Research in Education and Practice of Teachers (O papel da pesquisa na formação e na prática dos professores). Campinas: Papirus.

Balcikanli, C. (2011). Metacognitive Awareness Inventory for Teachers (MAIT). Electronic Journal of Research in Educational Psychology, 9, 1309-1332.

http://www.investigacion-psicopedagogica.com/revista/articulos/25/english/Art_25_563.pdf

Bransford, J., Brown, A., \& Cocking, R. (2007). How People Learn: Brain, Mind, Experience, and School (Como as pessoas aprendem: cérebro, mente, experiência e escola). São Paulo: Senac Publisher.

Brazil (1996). LDBEN, National Education Guidelines and Framework Law No. 9.394/96 (Lei de Diretrizes e Bases da Educação Nacional do Brasil n ${ }^{\circ}$ 9.394). Diário Oficial da União. http://www.planalto.gov.br/ccivil_03/leis/L9394.htm

Coltro, A. (2000). Phenomenology: A Methodological Approach beyond Modernity (A fenomenologia: Um enfoque metodológico para além da modernidade). Caderno de Pesquisa em Administração, 1, 37-45.

http://www.regeusp.com.br/arquivos/C11-art05.pdf

Curitiba's Department of Education (2006). Curriculum Guidelines for Municipal Education of Curitiba (Diretrizes Curriculares para a Educação Municipal de Curitiba) (2nd ed., Vol. 2). Curitiba: Early Childhood Education Department.

Curitiba's Department of Education (2009). Parameters and Quality Indicators for the Municipal Centers of Early Childhood Education (Parâmetros e indicadores de qualidade para os Centros Municipais de Educação Infantil). Curitiba: Early Childhood Education Department.

Fernandes, J. G. D. (2008). Revealing a Childhood Education Institution: A Training Service Experience with Early Childhood Professionals (Desvelando uma Instituição de Educação Infantil: Uma experiência de formação em serviço com profissionais da primeira infância) (130 p). Dissertation (Master Degree), Presidente Prudente, SP: Faculty of Science and Technology, Paulistana State University. http://www2.fct.unesp.br/pos/educacao/teses/juliana fernandes.pdf

Fernandes, S. C. (2000). Training Groups: Analysis of an In-Service Training Process from Perspective of Early Childhood Education Teachers (Grupos de formação: Análise de um processo de formação em serviço sob a perspectiva dos professores da educação infantil) (111 p). Dissertation (Master Degree), Florianópolis, Santa Catarina: Postgraduate Program of Education, Federal University of Santa Catarina.

http://portal.pmf.sc.gov.br/arquivos/arquivos/pdf/06_12_2011_11.31.00.f24336fd79d054fa150d4ebc0cf52512.pdf

Flavell, J., Miller, P., \& Miller, S. (1999). Cognitive Development [Desenvolvimento cognitivo] (3rd ed.). Porto Alegre: Artes Médicas.

Garcia, C. M. (1999). Teacher Training for Educational Change [Formação de professores para uma mudança educativa]. Porto: Porto Publisher.

Hollanda, M. P. D. (2007). Training at the Teachers of Early Childhood Education: A Case Study [Formação em Contexto de Professoras da Educação Infantil: Um estudo de caso] (294 p). Teses (Doctorade Degree in Education), Postgraduate Program of Education, Fortaleza: Federal University of Ceará.

http://www.repositorio.ufc.br/handle/riufc/3656

Mateos, M. (2001). Metacognition and Education [Metacognición y Educación]. Buenos Aires: Aique Grupo Editor AS.

Meinicke, D., \& Portal, L. L. F. (2014). Continuing Training of Teachers of Early Childhood Education: What Does CAPES Thesis Bank Unveils along Years 2011-2012? [Formação Continuada de Professores de Educação Infantil: O que revela o Banco de Teses da CAPES nos anos 2011-2012?]. Educação Por Escrito, 5, 256-273.

http://revistaseletronicas.pucrs.br/ojs/index.php/porescrito/article/viewArticle/18664 http://dx.doi.org/10.15448/2179-8435.2014.2.18664

Morin, E. (2001). The Well-Made Head: Rethink the Reform, Reform the Thought [A cabeça bem-feita: Repensar a reforma, reformar o pensamento] (4th ed.). Rio de Janeiro: Bertrand Brasil.

Nóvoa, A. (1992). The Teachers and Their Training [Os professores e sua formação]. Lisboa: Nova Enciclopédia.

Oliveira-Formosinho, J. (2009). Professional Development of Teachers [Desenvolvimento profissional dos professores]. In J. Formosinho (Coord.), Teacher Training: Professional Learning and Teacher Action [Formação de professores: Aprendizagem profissional e acção docente] (pp. 221-284). Porto: Porto Publisher.

Perrenoud, P. (2002). Reflective Practice in Teacher's Occupation: Professional and Pedagogical Reason [A prática reflexiva no ofício de professor: Profissionalização e razão pedagógica]. Porto Alegre: Artmed.

Placco, V. M. S., \& Souza, V. L. (2006). Learning of the Adult Teacher [Aprendizagem do Adulto Professor]. São Paulo: Loyola.

Portilho, E. (2009). How to Learn? Strategies, Styles and Metacognition [Como se aprende? Estratégias, estilos e metacog- 
nição]. Rio de Janeiro: Wak.

Portilho, E. M. L., \& Beltrami, K. (2011) Evaluation Instrument of Styles of Learning for Small Children. Problems of Education in the 21st Century, 38, 61-70. http://www.scientiasocialis.lt/pec/?q=node/651

Postholm, M. B. (2012). Teachers’ Professional Development: A Theoretical Review. Educational Research, 54, 405-429. http://www.tandfonline.com/doi/abs/10.1080/00131881.2012.734725\#.VnBHyvkrLIU http://dx.doi.org/10.1080/00131881.2012.734725

Sato, T. A. (2006). Participatory Action Research and Socio-Environmental Issues in the Continuing Education Process of Early Childhood Education Teachers [Pesquisa-ação-participativa e a temáticasócio-ambiental no processo de formaçãocontinuada de professoras da educaçãoinfantil] (114 p). Dissertation (Master Degree), Postgraduate Program of Education, São Paulo: Federal University of São Carlos.

http://www.bdtd.ufscar.br/htdocs/tedeSimplificado/tde_arquivos/8/TDE-2008-01-16T13:46:13Z-1707/Publico/1643.pdf

Schraw, G., \& Dennison, R. S. (1994). Assessing Metacognitive Awareness. Contemporary Educational Psychology, 19, 460-475. http://www.sciencedirect.com/science/article/pii/S0361476X84710332 http://dx.doi.org/10.1006/ceps.1994.1033

Segat, T. C., \& Grabauska, C. J. (2004). Investigative and Collaborative Actions in Teachers' Education Processes and Practices in Child Education [Ações investigativas e colaborativas no processo de formação de professores e nas práticas em educação infantil]. Educação (UFSM), 29, 81-90. http://cascavel.cpd.ufsm.br/revistas/ojs-2.2.2/index.php/reveducacao/article/viewArticle/3873

Silva, C. E. (2004) Continuing Education of Childcare Teachers: In Intervention Proposal [Formação continuada de educadoras infantis: Uma proposta de intervenção] (192 p). Dissertation (Master Degree), Postgraduate Program of Education, Uberlândia: Federal University of Uberlândia. http://www.bdtd.ufu.br//tde_busca/arquivo.php?codArquivo=2224

Tardif, M. (2006). Professional Knowledge and Teacher Training [Saberes Docentes e Formação Profissional]. Petrópolis: Vozes.

Veiga, I. P. A. (2009). The Adventure of Train Teachers [A Aventura de Formar Professores]. Campinas: Papirus.

Vignado, J. (2007). Challenges of Constructing a Graduated Collective Work Referred by Action-Research on Continued Educators Build-Up of Children Education [Desafios da construção de uma proposta de trabalho coletivo docente referenciada pela investigação-ação na formação continuada de professores de educação infantil] (276 p). Teses (Doctorade degree in Education), Postgraduate Program of Education, Campinas: Campinas State University.

http://www.bibliotecadigital.unicamp.br/document/?code=000416085\&fd=y

Zapelini, C. A. E. (2009). Educational Processes Developed in Childhood Education Institutions: An Experience of Continued Education [Processos formativos constituídos no interior das instituições de Educação Infantil: Uma experiência de formação continuada]. Pro-Posições, 20, 167-184. http://cat.inist.fr/?aModele=afficheN\&cpsidt=21837375

http://dx.doi.org/10.1590/S0103-73072009000200011 